\title{
Electrospray patterning of yeast cells for applications in alcoholic fermentation
}

\author{
Sang Bin Jeong ${ }^{1,3}$, Eui-seok Chong ${ }^{1,3}$, Ki Joon $\mathrm{Heo}^{1}$, Gun Woong Lee ${ }^{1}$, Hyung Joo Kim² \& \\ Byung Uk Lee ${ }^{1^{*}}$
}

Yeast cells patterned by pulsed jet electrospray showed a high alcoholic fermentation rate. Multidimensional patterns of individual yeast cells were produced by varying the experimental parameters of the electrospray system. The electrospray process, which employed a vibrational electric field, could control patterns of viable yeast cells at a cellular resolution. This novel system for electrospraying viable cells can be applied to biological process engineering including whole cell biochip techniques and micro fermentation processes for biochemical studies.

\begin{abstract}
The immobilization of cells on solid surfaces has been applied in the development of bioreactors, biochemical tests, and in vitro pharmacokinetics. Microenvironments on solid surfaces enhance cell stability, cell recycling, and downstream cellular processes ${ }^{1}$. Microcontact printing, photolithography, dip-pen nanolithography, and inkjet printing are considered as methods for patterning biomaterials on substrates ${ }^{2-6}$. However, these patterning methods have drawbacks as they can be time-consuming (microcontact printing and photolithography), induce chemical damages on cells (dip-pen nanolithography), or be inaccurate in controlling the position of individual cells (microcontact printing, photolithography, and inkjet printing) ${ }^{6,7}$. An electrospray method developed for the atomization of fine droplet particles ${ }^{8-12}$ has been applied for the accurate analysis of biological particles ${ }^{13-16}$. As a new application for the electrospraying technique, cell patterning using an electrospray pulsed jet was developed $^{17,18}$, and this method allowed accurate immobilization of individual cells on an untreated substrate without chemical damage ${ }^{19}$. Previous studies presented that non-agglomerated cells that were electrically charged via pulsed electrical fields between a nozzle and a ground plate in the electrospray system showed patterns at a cellular resolution ${ }^{18,20-22}$. In this study, an electrospray patterning system for yeast cells was created. The patterns of individual yeast cells were fabricated at a cellular resolution, and the electrospray-patterned cells showed high-speed alcoholic fermentation rates.
\end{abstract}

\section{Results}

Electrospray patterning of live yeast cells. We generated line patterns of materials at a translation speed of $1 \mathrm{~mm} / \mathrm{s}$ under a vibrating electrical field of $0.8 \mathrm{kV}$ and at a frequency of $20 \mathrm{~Hz}$. Nutrient broth media were patterned at a flow rate of $5 \mu \mathrm{L} / \mathrm{h}$ and incubated at $25^{\circ} \mathrm{C}$ for $24 \mathrm{~h}$. The line patterns of clean nutrient broth medium (Becton Dickinson, Franklin Lakes, NJ, USA) (Fig. 1a) had an average width of $191 \mu \mathrm{m}$, and the broth medium patterns before and after incubation did not show significant differences. Aside from the evaporation on the edges, the broth medium mostly maintained its shape after incubation as showed in Fig. 1a. Figure 1b demonstrates the yeast cell patterns before and after incubation. The line patterns of broth medium containing yeast cells (Fig. 1b) had an average width of $252 \mu \mathrm{m}$. In addition, Fig. $1 \mathrm{~b}$ shows that the patterned yeast medium generated a darker line in the middle with an average width of $79 \mu \mathrm{m}$ after incubation. This dark line seems to be the extracellular matrix (ECM) that acts as a cell-supporting scaffold ${ }^{23}$, indicating that the yeast cell viability did not vanish even after the cells passed through the electrospray patterning system. The viability of the patterned yeast cells was also confirmed by an increase in the number of incubated yeast cells (Fig. 1b).

One-dimensional drop-on-demand patterning of yeast cells. Figure 2 a shows the drop-on-demand patterning of yeast cells, which consisted of spots with a regular diameter of $50 \mu \mathrm{m}$ and an average inter-spot

\footnotetext{
${ }^{1}$ Aerosol and Bioengineering Laboratory, Department of Mechanical Engineering, Konkuk University, 120 Neungdong-ro, Gwangjin-gu, Seoul, 05029, Republic of Korea. ${ }^{2}$ Department of Biological Engineering, Konkuk University, 120 Neungdong-ro, Gwangjin-gu, Seoul, 05029, Republic of Korea. ${ }^{3}$ These authors contributed equally: Sang Bin Jeong and Eui-seok Chong. *email: leebu@konkuk.ac.kr
} 


\section{(a) Line pattern of clean broth media}

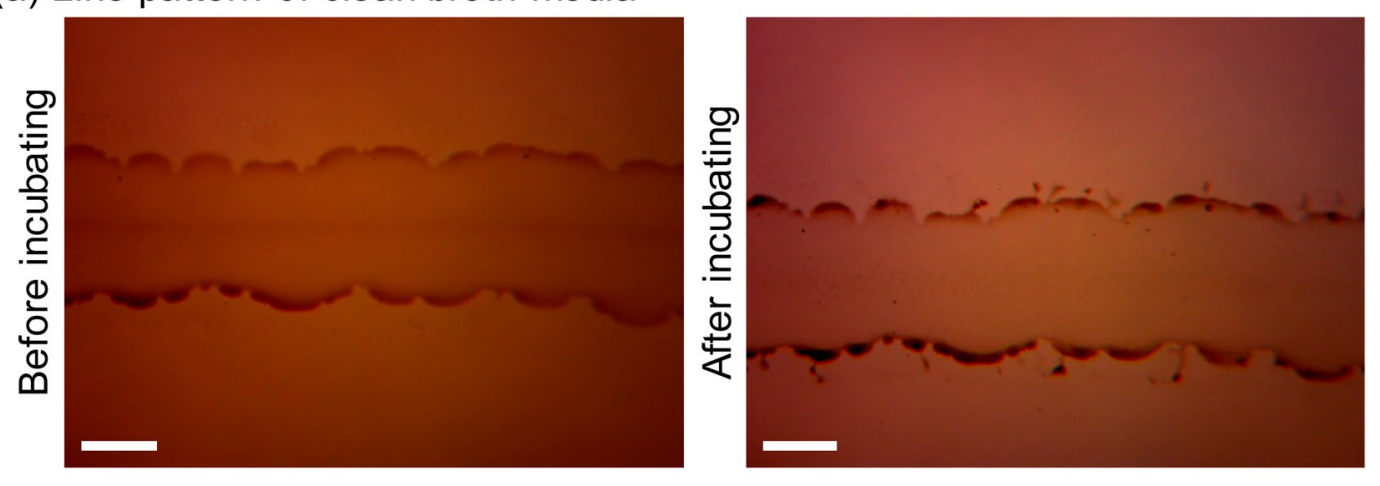

(b) Line pattern of broth media contain yeast cells
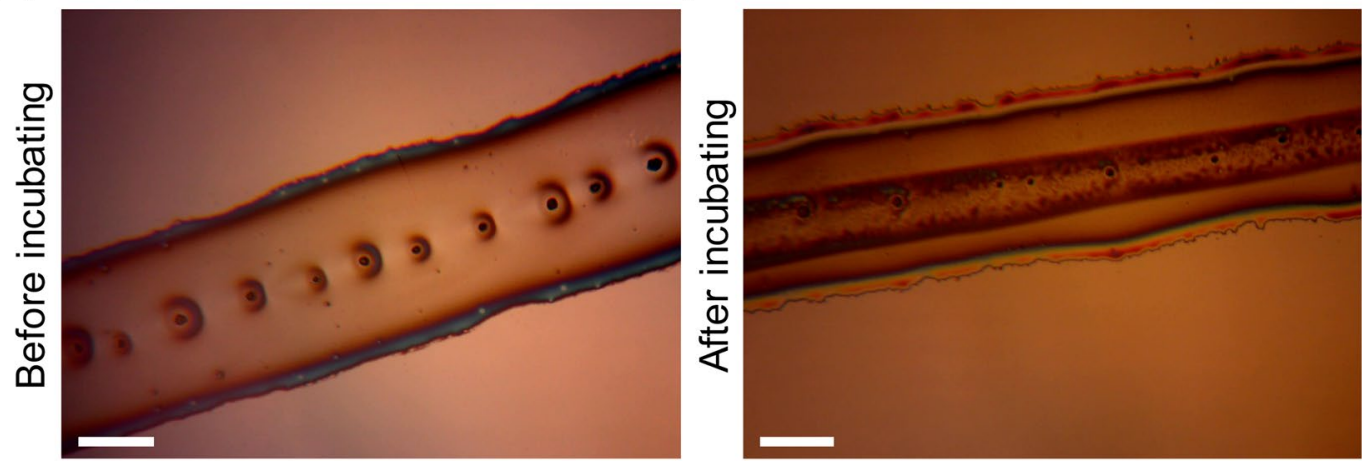

Figure 1. Electrospray line pattern of broth medium and yeast cell (Saccharomyces cerevisiae) containing medium. (a) Line pattern of broth medium without yeast cells. (b) Line pattern of yeast cell-containing medium. Incubation was conducted at $25^{\circ} \mathrm{C}$ for $24 \mathrm{~h}$ after the deposition process. Scale bars represent $100 \mu \mathrm{m}$.

distance of $158 \mu \mathrm{m}$. Individual spots contained one yeast cell or very few cells, indicating that the aggregating nature of yeast cells could be controlled by electric forces in the electrospray system. The distance between the droplets could be varied by adjusting translation speed, which ranged from 0.5 to $1.5 \mathrm{~mm} / \mathrm{s}$. As the translation speed decreased, the distance between two droplets also decreased. The inter-spot distance was $83 \mu \mathrm{m}$ at a translation speed of $1 \mathrm{~mm} / \mathrm{s}$ (Fig. 2b) and decreased to $30 \mu \mathrm{m}$ at a speed of $0.5 \mathrm{~mm} / \mathrm{s}$ (Fig. 2c). In addition, the droplet size and number of cells in a single droplet decreased at higher translation speeds.

The high-resolution images of yeast patterns (Fig. 3) demonstrate that the droplet diameters varied with the flow rates. Small droplets were produced at a flow rate of $4 \mu \mathrm{L} / \mathrm{h}$ and large droplets were produced at $5 \mu \mathrm{L} / \mathrm{h}$ (Fig. 3a). The experimental conditions (translation speed of $2 \mathrm{~mm} / \mathrm{s}$, alternating-current (AC) electricity at $0.8 \mathrm{kV}$, and frequency of $20 \mathrm{~Hz}$ ) were identical in these two cases. The geometric mean diameters of the small and large droplets were $103 \mu \mathrm{m}$ and $128 \mu \mathrm{m}$, respectively. Single yeast cells with a diameter of $3 \mu \mathrm{m}$ and an elliptical shape were patterned in individual spots, as shown in Fig. 3b,c. In addition, the patterned yeast cells tended to localize at the center of each droplet. The cone-jet electrospraying mode generated highly electrically charged monodisperse droplets and particles. The electrostatic repulsive forces of these particles may cause them to repel each other. Therefore, individual yeast cells in the droplets may be localized in the center of the spots because of the balance among the electrostatic repulsive forces ${ }^{24,25}$.

Fermentation efficiency of electrospray-patterned yeast cells. In this experiment, alcoholic fermentation by the patterned yeast cells was performed using a solution of squeezed grapes. Alcohol concentration was measured over $120 \mathrm{~h}$ in all individual tests and served as an indicator of fermentation in the solution. Squeezed grape solutions without yeast cells were used as control materials for the experiment. We hypothesized that the fermentation efficiency was correlated with how yeast cells were spread in the grape solution under the same cell number conditions. To verify this hypothesis, we conducted experiments with yeast cells under various conditions: dropping the yeast medium using a pipette ("No-patterned"); using an air pressure unit ("fine-mist sprayer"); and positioning yeast cells inside the solution with electrospray droplet patterns of $30 \mu \mathrm{m}, 100 \mu \mathrm{m}$, or $1,000 \mu \mathrm{m}$ ("patterned").

Figure 4 shows the experimental fermentation results. The alcohol concentration in the control solution (incubation without yeast cells) ranged from $0.1 \%$ to $0.3 \%$. Yeast cells artificially mixed in the grape solution induced the fermentation process. The alcohol concentration in the yeast solutions converged from $8 \%$ to $8.4 \%$ after $120 \mathrm{~h}$ of fermentation. However, the fermentation rate varied significantly depending on the type of yeast cell spreading in the grape solution. Yeast cells patterned at $30 \mu \mathrm{m}$ showed the highest fermentation rate, whereas those without patterns presented the lowest rate. The fermentation rate increased from $0.08 \%$ per hour to $0.1 \%$ per hour by 
(a)

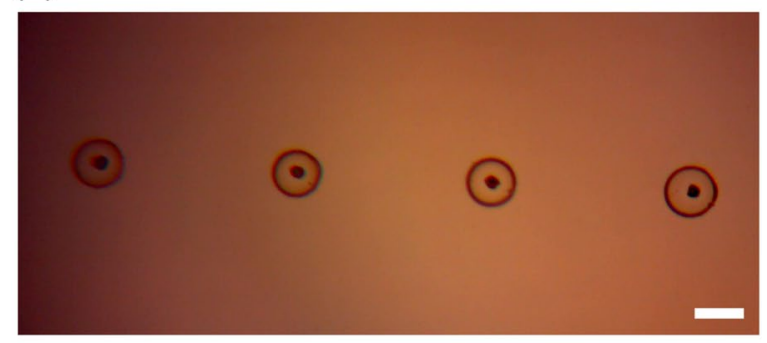

(b)

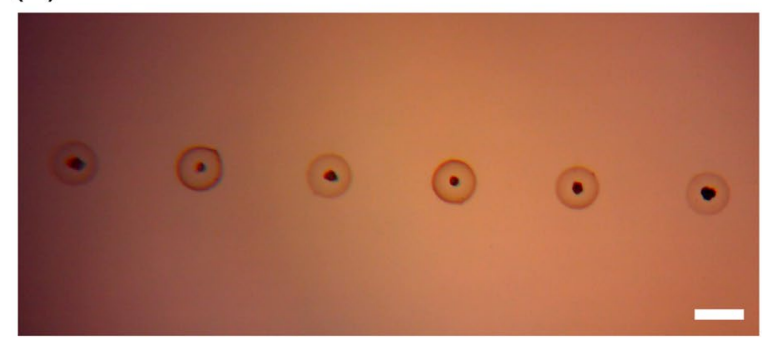

(c)

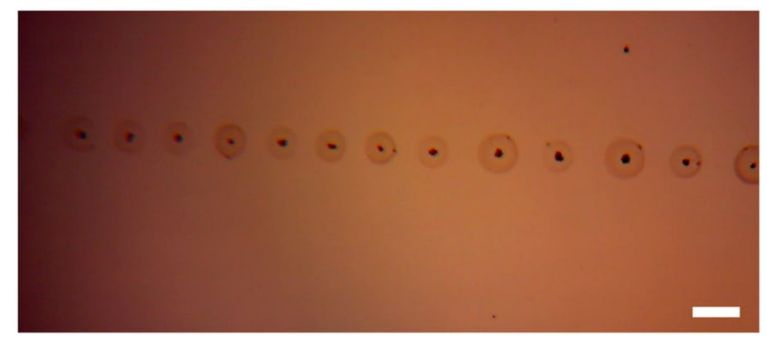

Figure 2. One-dimensional patterned yeast cell medium. The average distances between the center points of two droplets were (a) $158 \mu \mathrm{m}$ at a translation speed of $1.5 \mathrm{~mm} / \mathrm{s}$, (b) $83 \mu \mathrm{m}$ at a translation speed of $1 \mathrm{~mm} / \mathrm{s}$, and (c) $30 \mu \mathrm{m}$ at a translation speed of $0.5 \mathrm{~mm} / \mathrm{s}$. Scale bars represent $50 \mu \mathrm{m}$.

varying yeast cell spreading from the non-patterned to the patterned form (at $30 \mu \mathrm{m}$ ). As shown in Fig. 4, the $30 \mu \mathrm{m}$ pattern showed the highest fermentation efficiency at all time points. Furthermore, the $30 \mu \mathrm{m}$ pattern decreased the time for alcohol production via yeast cell fermentation by $25 \%$. This result demonstrates that yeast cell patterning can be applied to increase the alcohol production rate by fermentation.

Figure $2 \mathrm{c}$ shows the small droplets that were produced by patterning the cells at $30 \mu \mathrm{m}$. As the droplet size decreased, contact between the squeezed grape solution and yeast cells was promoted, which was expected to increase the amounts of the fermentation reactions on the droplet surfaces. The effect of specific electrospray operating conditions such as flow rate, frequency, and voltage on yeast fermentation efficiency could be explored in future studies on yeast cell electrospray patterning systems. Our study focused on the fermentation potential of viable electrospray-patterned yeast cells, and we did not explore the usage of the produced alcohol in products such as fuel or beverages. In the future, to apply this new technology for the production of such commodities, its effect on flavor and production speed would need to be tested.

\section{Conclusions}

A new electrospray drop-on-demand patterning system was created to pattern viable yeast cells at a cellular resolution. Viable electrospray-patterned yeast cells showed high-speed alcoholic fermentation rates. In this experiment, the $30 \mu \mathrm{m}$ droplet pattern of yeast cells showed the most efficient performance in alcohol fermentation. This electrospray cell patterning technology can be applied to biochemical engineering and fermentation industries.

\section{Methods}

Figure 5a shows the experimental configuration of the electrospray patterning system, which was created based on our previous study ${ }^{18}$. The experimental setup consisted of a liquid supply system with a capillary tube, a high-voltage power supply system, a ground plate with a translation system, and a visualization system. A yeast suspension was loaded into silica capillaries (PicoTip emitter, New Objective, USA) with a diameter of $30 \mu \mathrm{m}$ using a $25 \mu \mathrm{L}$ syringe (1702TLL, Hamilton, USA) and a syringe pump (Model 220, KD Scientific, USA). A power supply device (DC-AC 15kV, Korea Switching, Korea) with a function generator (FG-7002C, EZ Digital, Korea) was used to generate an electric field between the silica capillaries and the ground plate. Electricity was applied to a stainless steel ZDV union (U-322, Upchurch, USA) to confer charge to the passing yeast cell suspension during electrospraying. A silicon wafer with a diameter of $12 \mathrm{~cm}$ placed on a stainless steel plate was used as a 
(a)

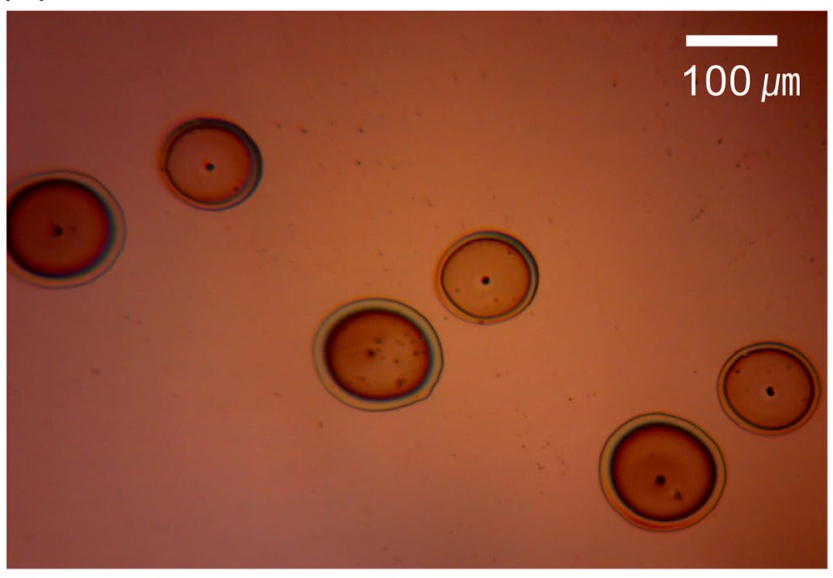

(b)

(c)
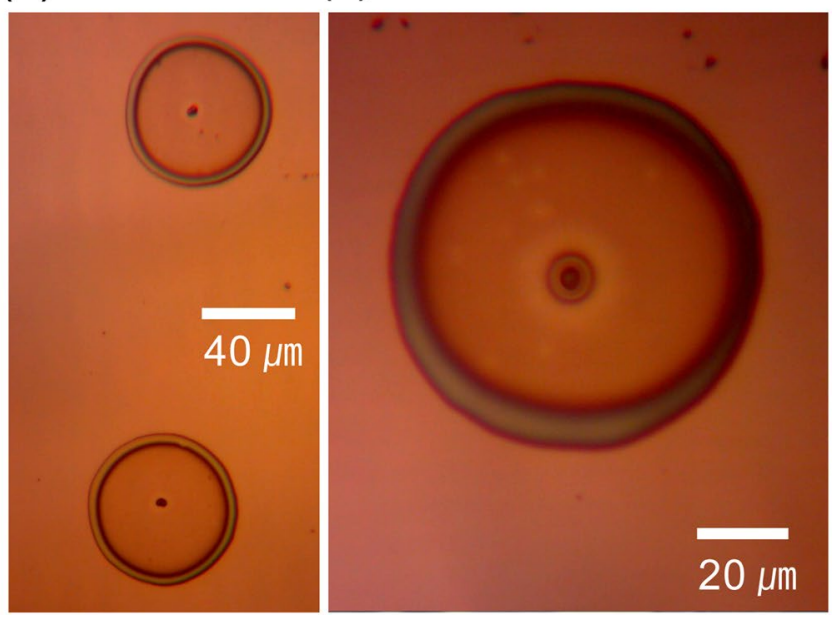

Figure 3. Magnified photographs of yeast cells patterned using the electrospray system. (a) Six patterned yeast cells. (b) Two patterned yeast cells (yeast cells located at the center of the individual spots). (c) Single yeast cell at the center of the droplet.

(a)

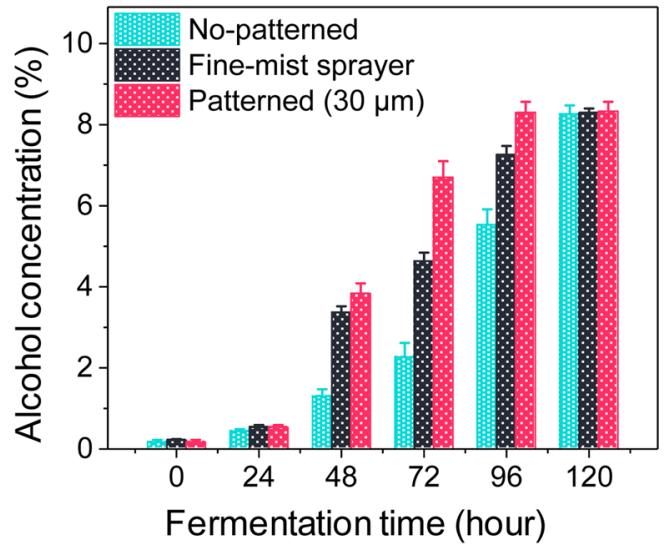

(b)

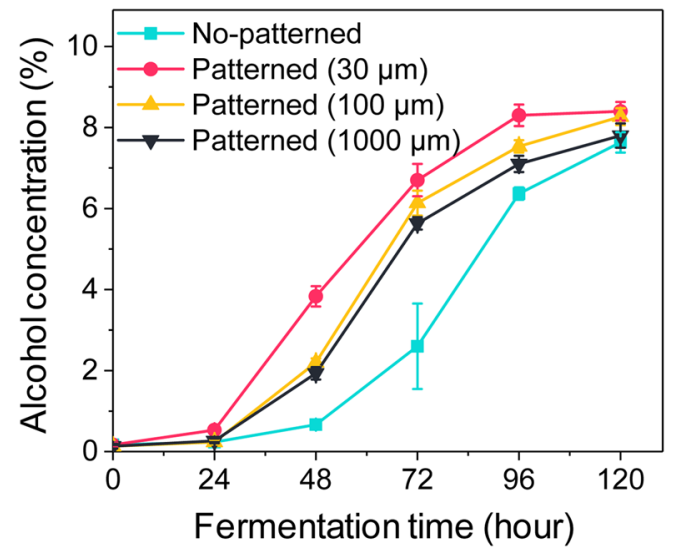

Figure 4. Alcohol concentrations during the fermentation processes. (a) Fermentation conditions: dropping the yeast medium using a pipette ("No-patterned"); using an air pressure unit ("fine-mist sprayer"); and positioning yeast cells inside the solution with electrospray patterns of $30 \mu \mathrm{m}$ ("patterned"). (b) Fermentation conditions: ("No-patterned") and ("patterned") with $30 \mu \mathrm{m}, 100 \mu \mathrm{m}$, and 1,000 $\mu \mathrm{m}$ droplet patterns. Error bars indicate standard deviations $(\mathrm{n}=3)$. 
(a)

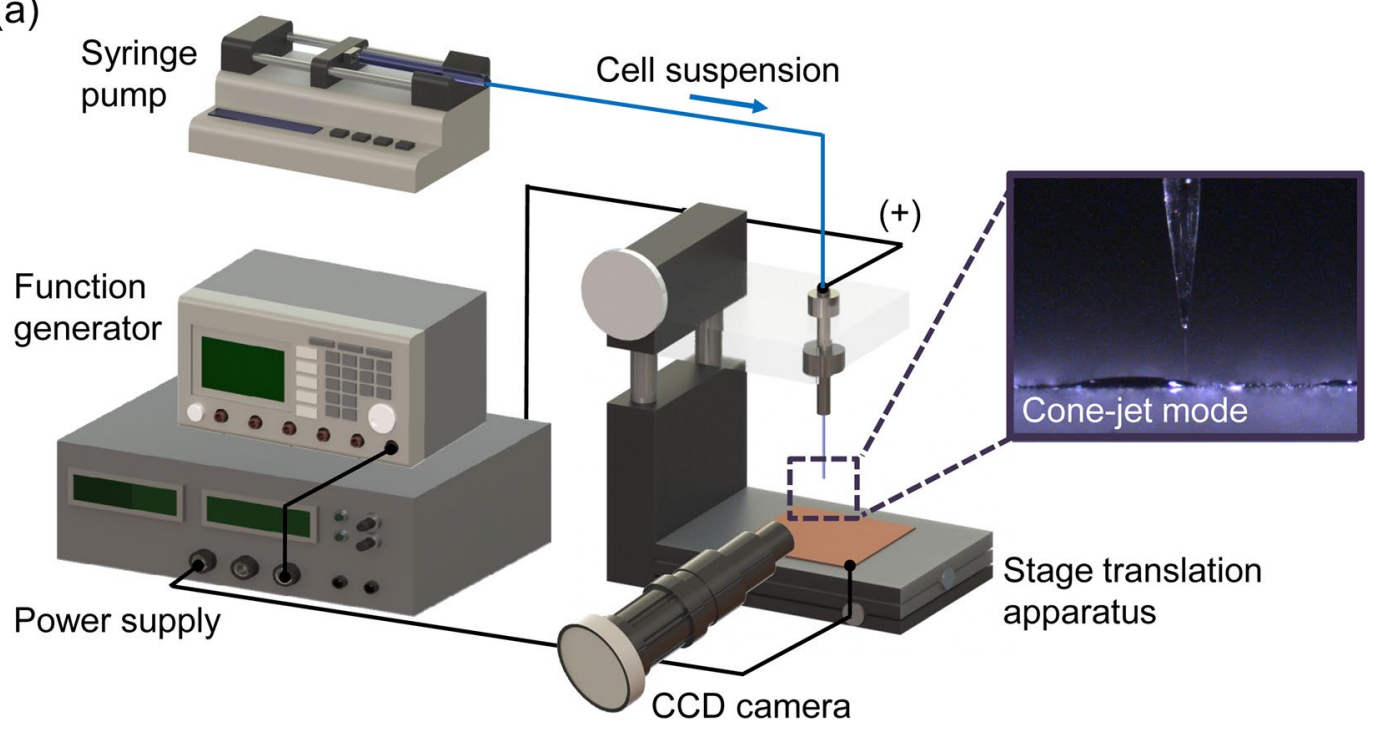

(b)
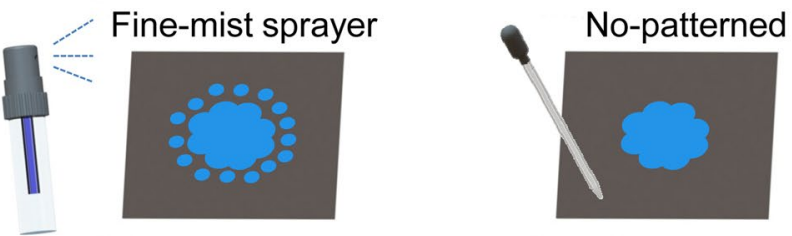

Patterned

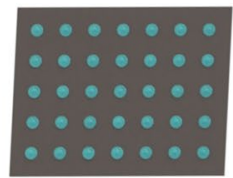

Figure 5. (a) Schematic diagram of the electrospray patterning system for yeast cells. The stable cone-jet mode and two-way stage translation apparatus enabled patterning of living cells. (b) Various yeast cell spreading conditions: spreading using a fine-mist sprayer, non-patterned spreading, and patterned spreading with cell distances of 30,100 , and $1,000 \mu \mathrm{m}$.

ground plate for the electrospray system. A two-dimensional stage translation apparatus with adjustable constant speed was used to produce patterns of suspension particles in a vibrating electrical field between the capillary tip and the ground plate installed $1 \mathrm{~mm}$ below. The visualization system shown in Fig. 5a, which consisted of a light source (LS-100W, Light Solution, Korea) and a charge coupled device camera (Marlin F-145C2, Allied Vision Tech, Germany) with a zoom lens (70XL, OPTEM, Korea), was employed to monitor the electrospray mode in real time. In addition, the yeast particle patterns produced on the wafer were observed by an optical microscope (Eclipse ME600, Nikon, Japan) equipped with a charge-coupled device camera (INFINITY1, Lumenera Co., Canada).

For the drop-on-demand patterning experiments, electricity was supplied at $0.8 \mathrm{kV}$ with a frequency of $20 \mathrm{~Hz}$ by a high-voltage power supply system. We applied vibrating sinusoidal high-voltage electricity at several kilovolts to the capillary by means of a high-voltage AC power supply $(\mathrm{AC}+15 \mathrm{kV}$, Korea Switching, Korea) and a function generator (FG-7002C, EZ Digital, Korea). To observe the characteristics of the applied electric voltage, we used a 1/1000 AC high-voltage reduction probe (P6015A, Tektronix, USA) and an oscilloscope (TDS2014, Tektronix, USA). In the experiments, the distance between spots and the droplet diameter were controlled by adjusting the speed of the stage translation apparatus from 0.5 to $2.0 \mathrm{~mm} / \mathrm{s}$. The flow rate of the syringe pump ranged from $3 \mu \mathrm{L} / \mathrm{h}$ to $5 \mu \mathrm{L} / \mathrm{h}$. To determine the viability of patterned yeast cells, we incubated them at $25^{\circ} \mathrm{C}$ as these conditions were known to be adequate for fermentation ${ }^{26}$.

For the alcoholic fermentation experiments, Saccharomyces cerevisiae (Korean Collection for Type Cultures, KCTC 7904) was used as the test yeast strain. We cultivated the S. cerevisiae cells in YPD (10 g/L Yeast extract, $20 \mathrm{~g} / \mathrm{L}$ Peptone, $20 \mathrm{~g} / \mathrm{L}$ Dextrose) medium at $30^{\circ} \mathrm{C}$. Stationary phase yeast cells were harvested through centrifugation $(4000 \times \mathrm{g}, 15 \mathrm{~min})$. We constructed an acrylic box $(80 \mathrm{~mm} \times 60 \mathrm{~mm} \times 60 \mathrm{~mm}$ in size $)$ that was internally separated by two partitions (thickness: $5 \mathrm{~mm}$; height: $30 \mathrm{~mm}$ ). Various yeast cell spreading conditions, such as the use of a fine-mist sprayer, non-patterned spreading, and patterned spreading with cell distances of 30, 100, and 1,000 $\mu \mathrm{m}$ were used in the fermentation experiments to analyze the effect of yeast cell arrangement on fermentation efficiency (Fig. $5 b)$. Under all conditions, $1 \mathrm{~mL}$ of yeast cell medium $\left(\sim 10^{6}\right.$ colony forming units, CFU/mL) was spread on a silicon wafer and incubated with $200 \mathrm{~mL}$ of squeezed grape solution (sugar content: $27.2 \mathrm{~g} / 200 \mathrm{~mL}$ ) at $25^{\circ} \mathrm{C}$ for a maximum of $120 \mathrm{~h}$ in the acrylic box. The alcohol concentration in the tested solutions was measured using an alcolyzer (Anton Paar DMA 4500, Alcolyzer Wine, Austria). In the yeast cell patterned spreading conditions, the flow rate of yeast medium supplied to the system was $0.2 \mathrm{~mL} / \mathrm{h}$, the spray tip had an inner diameter of $100 \mu \mathrm{m}$, and the applied electricity was AC $3 \mathrm{kV}$. In addition, the patterned cell distances were controlled by adjusting the speed of the stage transition apparatus $(0.5-8.5 \mathrm{~mm} / \mathrm{s})$. 
Received: 2 July 2019; Accepted: 15 November 2019;

Published online: 09 December 2019

\section{References}

1. Kourkoutas, Y., Bekatorou, A., Banat, I. M., Marchant, R. \& Koutinas, A. A. Immobilization technologies and support materials suitable in alcohol beverages production: a review. Food Microbiol. 21, 377-397 (2004).

2. Renault, J. P. et al. Fabricating microarrays of functional proteins using affinity contact printing. Angewandte Chemie 114, 2426-2429 (2002).

3. Revzin, A., Tompkins, R. G. \& Toner, M. Surface engineering with poly (ethylene glycol) photolithography to create high-density cell arrays on glass. Langmuir 19, 9855-9862 (2003).

4. Lee, K. B., Park, S. J., Mirkin, C. A., Smith, J. C. \& Mrksich, M. Protein nanoarrays generated by dip-pen nanolithography. Science 295, 1702-1705 (2002).

5. Xu, T., Kincaid, H., Atala, A. \& Yoo, J. J. High-throughput production of single-cell microparticles using an inkjet printing technology. J. Manuf. Sci. Eng. 130, 021017 (2008).

6. Gross, A. et al. Single-cell printer: automated, on demand, and label free. J. Lab. Autom. 18, 504-518 (2013).

7. Jayasinghe, S. N. \& Townsend-Nicholson, A. Bio-electrosprays: the next generation of electrified jets. Biotechnol. J. 1, 1018-1022 (2006).

8. Nakaso, K., Han, B., Ahn, K. H., Choi, M. \& Okuyama, K. Synthesis of non-agglomerated nanoparticles by an electrospray assisted chemical vapor deposition (ES-CVD) method. J. Aerosol Sci. 34, 869-881 (2003).

9. Xie, J., Lim, L. K., Phua, Y., Hua, J. \& Wang, C. Electrohydrodynamic atomization for biodegradable polymeric particle production. J. Colloid Interf. Sci. 302, 103-112 (2006).

10. Jaworek, A. Electrospray droplet sources for thin film deposition. J. Mater. Sci. 42, 266-297 (2007).

11. Paine, M. D., Alexander, M. S., Smith, K. L., Wang, M. \& Stark, J. P. W. Controlled electrospray pulsation for deposition of femtoliter fluid droplets onto surfaces. J. Aerosol Sci. 38, 315-324 (2007).

12. Park, J. U. et al. High-resolution electrohydrodynamic jet printing. Nat. Mater. 6, 782-789 (2007).

13. Fenn, J. B., Mann, M., Meng, C. K., Wong, S. F. \& Whitehouse, C. M. Electrospray Ionization for Mass Spectrometry of Large Biomolecules. Science 246, 64-71 (1989).

14. Gomez, A., Bingham, D., de Juan, L. \& Tang, K. Production of protein nanoparticles by electrospray drying. J. Aerosol Sci. 29, 561-574 (1998)

15. Morozov, V. N. \& Morozova, T. Y. Electrospray Deposition as a Method for Mass Fabrication of Mono- and Multicomponent Microarrays of Biological and Biologically Active Substances. Anal. Chem. 71, 3110-3117 (1999).

16. Bhatnagar, P. Multiplexed electrospray deposition for protein microarray with micromachined silicon device. Appl. Phys. Lett. 91, 014102 (2007).

17. Kim, K. et al. Use of an electrospray for the generation of bacterial bioaerosols. J. Aerosol Sci. 39, 365-372 (2008)

18. Kim, K., Lee, B. U., Hwang, G. B., Lee, J. H. \& Kim, S. Drop-on-demand patterning of bacterial cells using pulsed jet electrospraying. Anal. Chem. 82, 2109-2112 (2010).

19. Chong, E. S. et al. Viable bacterial cell patterning using a pulsed jet electrospray system. J. Microbiol. Biotechnol. 25, 381-385 (2015).

20. Hayati, I., Bailey, A. I. \& Tadros, T. F. Mechanism of stable jet formation in electrohydrodynamic atomization. Nature 319, 41-43 (1986).

21. Whitehouse, C. M., Dreyer, R. N., Yamashita, M. \& Fenn, J. B. Electrospray ionization for mass-spectrometry of large biomolecules. Science 246, 64-71 (1989).

22. Wu, Y., Fei, Z., Lee, L. J. \& Wyslouzil, B. E. Coaxial electrohydrodynamic spraying of plasmid DNA/polyethylenimine (PEI) polyplexes for enhanced nonviral gene delivery. Biotechnol. Bioeng. 105, 834-841 (2010).

23. Faria-Oliveira, F. et al. Methodologies to generate, extract, purify and fractionate yeast ECM for analytical use in proteomics and glycomics. BMC Microbiol. 14, 244 (2014).

24. Wilhelm, O., Mädler, L. \& Pratsinis, S. E. Electrospray evaporation and deposition. J. Aerosol Sci. 34, 815-836 (2003).

25. Jung, J. H., Oh, H. \& Kim, S. S. Numerical simulation of the deposition pattern in multiple electrohydrodynamic spraying. Powder Technol. 198, 439-444 (2010).

26. Torija, M. J., Rozes, N., Poblet, M., Guillamón, J. M. \& Mas, A. Effects of fermentation temperature on the strain population of Saccharomyces cerevisiae. Int J Food Microbiol. 80, 47-53 (2003).

\section{Acknowledgements}

This paper was supported by Konkuk University in 2018.

\section{Author contributions}

S.B.J., E.S.C. and B.U.L. designed the experimental systems and conceived the study. B.U.L. coordinated the experiments. E.S.C. and S.B.J. fabricated most of the experimental systems. S.B.J., E.S.C., K.J.H., G.W.L. and B.U.L. conducted the experiments. B.U.L. and S.B.J. analyzed the results. B.U.L. and S.B.J. wrote the paper with the help of H.J.K. K.J.H. and H.J.K. provided assistance for analysis of the results.

\section{Competing interests}

The authors declare no competing interests.

\section{Additional information}

Correspondence and requests for materials should be addressed to B.U.L.

Reprints and permissions information is available at www.nature.com/reprints.

Publisher's note Springer Nature remains neutral with regard to jurisdictional claims in published maps and institutional affiliations. 
(c) (i) Open Access This article is licensed under a Creative Commons Attribution 4.0 International License, which permits use, sharing, adaptation, distribution and reproduction in any medium or format, as long as you give appropriate credit to the original author(s) and the source, provide a link to the Creative Commons license, and indicate if changes were made. The images or other third party material in this article are included in the article's Creative Commons license, unless indicated otherwise in a credit line to the material. If material is not included in the article's Creative Commons license and your intended use is not permitted by statutory regulation or exceeds the permitted use, you will need to obtain permission directly from the copyright holder. To view a copy of this license, visit http://creativecommons.org/licenses/by/4.0/.

(C) The Author(s) 2019 